\title{
Allelopathic effect of Sphenoclea zeylanica Gaertn. on rice (Oryza sativa L.) germination and seedling growth
}

\author{
Ramida Krumsri ${ }^{1}$, Hisashi Kato-Noguchi ${ }^{1}$, Thanatsan Poonpaiboonpipat ${ }^{2 *}$ \\ ${ }^{1}$ Department of Applied Biological Science, Faculty of Agriculture, Kagawa University, Miki, Kagawa 761-0795, Japan \\ ${ }^{2}$ Department of Agricultural Science, Faculty of Natural Resources and Environment, Naresuan University, Phitsanulok, \\ Thailand, 65000
}

\section{*Corresponding author: thanatchasanhap@nu.ac.th}

\begin{abstract}
The allelopathic effect of Sphenoclea zeylanica Gaertn., a broadleaf paddy weed that hinders rice production in Thailand, was investigated. Different parts of S. zeylanica were used to determine their inhibitory effect on seed germination, and shoot and root length of rice in a laboratory. Aqueous extracts of leaves and stems had an inhibitory effect on rice germination and seedling growth more than $50 \%$ that of control at concentrations higher than $50 \mathrm{~g} \mathrm{~L}^{-1}$, whereas all concentrations of root extracts had no effect on rice seeds. At the concentration of $100 \mathrm{~g} \mathrm{~L}^{-1}$, leaf and stem extracts completely (100\%) inhibited rice seed germination. The inhibitory effect was increased with increasing concentrations. Additionally, leaf extracts contained higher total phenolics (7.36 mg GE $\left.\mathrm{g}^{-1} \mathrm{DW}\right)$ and total flavonoids (254.19 $\mu \mathrm{g}$ QE g ${ }^{-1} \mathrm{DW}$ ) than extracts of other parts. In glasshouse conditions, soil incorporation with dried whole plant residue had a significant inhibitory effect on rice emergence, seedling height, and dry weight when compared with extracted residue at an equal concentration. The decomposition of $S$. zeylanica in the soil was also evaluated regarding rice seedling growth. The maximum inhibition was achieved 1-3 days after the application of plant residues. At the $30^{\text {th }}$ day, the inhibition disappeared, suggesting that residue decomposition in the soil has been finished. These results support that $S$. zeylanica has an allelopathic effect on paddy fields, which may cause a reduction in rice growth and yield.
\end{abstract}

Keywords: Sphenoclea zeylanica, Allelopathy, Rice, Seed bioassay, Soil incorporation, Soil decomposition.

Abbreviation: $\mathrm{g} \mathrm{L}^{-1}$ _gram per liter, $\mathrm{mg} \mathrm{GE} \mathrm{g}^{-1} \mathrm{DW} \_$milligram gallic acid equivalent per gram of plant dry weight, $\mu \mathrm{g}$ QE $\mathrm{g}^{-1}$ DW_microgram quercetin equivalent per gram of plant dry weight.

\section{Introduction}

Weeds compete with crops for different factors, including light, water, nutrients, and carbon dioxide; and produce metabolites to suppress crop growth and development, which is called allelopathy. Allelopathy is defined as any process involving secondary metabolites produced by plants, microorganisms, viruses, or fungi that influence the growth and development of agricultural and biological systems (Torres et al., 1996). The metabolites (allelochemicals) from plants are released either by leaf volatilization due to rain, fog, or dew, or by root exudation due to decomposing sloughed roots, leaves, fruits, or twigs (Xuan et al., 2005). Major biosynthetic pathways leading to the production of allelochemicals are known to be shikimic acid or acetate pathways (Rice, 1984). Especially, phenolic compounds include simple aromatic phenols, hydroxy and substituted benzoic acids and aldehydes, hydroxy and substituted cinnamic acids, coumarins, tannins, and flavonoids are major groups of allelochemical in plants, and they play key roles in the ecosystem (Inderjit, 1996). These phenolic compounds affect various physiological processes related to growth and development at various stages of a plant
(Zeng et al, 2008; Fu et al., 2019). Many reports attest that weeds can produce substances that suppress the growth of associated crops (Rice, 1984). For example, Sonchus arvensis L., an Asteraceae family weed generally distributed in crop fields, was reported to have an allelopathic effect on maize caused by aqueous leachates and residue incorporation with soil (Bashir et al., 2018). The soil incorporation of Echinochloa colona (L.) Link, a widely distributed grass weed, also reduces maize emergence and seedling growth (Majeed et al., 2018), and leaf leachates from Hyptis saveolens, Parthenium hysterophorus, and Tridax procumbens inhibit seed germination and seedling growth of Vigna mungo (L). Hepper (Babu et al., 2014). Moreover, the accumulation and persistence of allelochemicals in the soil after residue incorporation need to be determined.

Sphenoclea zeylanica Gaertn. is an annual herbaceous weed belonging to the Sphenocleaceae family. While being a native species in South Africa, it is now distributed worldwide in tropical and subtropical regions. S. zeylanica is a serious hindrance for rice growth in 17 countries; these include India, Pakistan, and countries in the Caribbean and Southeast Asia 
(Holm et al., 1977). In Thailand, S. zeylanica is a common weed in paddy rice, as well as a serious weed in transplanted rice. Found in about $25 \%$ of fields, it is fourth among the 10 most common weed species in the Central Plain (Chootummatat et al., 1994). S. zeylanica is a dominant weed species in paddy rice; it can be highly competitive for nutrients, light, water, and carbon dioxide and release toxic substances that suppress the growth of associated weeds. Premasthira and Zungsontiporn (2003) reported that the methanol extract of $S$. zeylanica suppressed the shoot and root growth in Leptochloa chinensis (L.) Nees, Chloris barbata Sw., Dactyloctenium aegyptium (L.) B.P., Pennisetum pedicellatum Trin., Pennisetum setosum L.C. Rich., Hygrophila erecta Hochr., Mimosa invisa var. inermis Adelb., Hyptis suaveolens Poit., and Scirpus articulatus L.

To understand effects of $S$. zeylanica on rice, this research aimed to (i) investigate the effect of aqueous extracts of different parts on rice with a seed bioassay test, (ii) analyze the water extracts' total phenolic and flavonoid content, (iii) examine the effect of $S$. zeylanica soil incorporation on rice growth and yield in pot conditions, and (iv) study the decomposition of the soil incorporation.

\section{Results and Discussion}

\section{Effect of different part extracts of S. zeylanica on rice germination and seedling growth}

Table 1 shows the aqueous extracts of three parts of $S$. zeylanica on rice germination and seedling growth. Leaf and stem extracts completely inhibited the germination $10 \%$ germination) at a concentration of $100 \mathrm{~g} \mathrm{~L}^{-1}$ and inhibited germination by $65 \%$ (35\% of seed germination) and $50 \%$ at 50 $\mathrm{g} \mathrm{L}^{-1}$, respectively. However, these extracts were not significant at 12.5 and $25 \mathrm{~g} \mathrm{~L}^{-1}$. The effect on seedling growth was exhibited in shoot and root lengths. At $100 \mathrm{~g} \mathrm{~L}^{-1}$, the leaf and stem extracts completely inhibited seedling growth because they completely inhibited seed germination. The leaf and stem extracts significantly inhibited shoot and root length at $50 \mathrm{~g} \mathrm{~L}^{-1}$. Shoot length at 12.5 and $25 \mathrm{~g} \mathrm{~L}^{-1}$ were not different when compared with distilled water (control). The leaf extracts at $12.5 \mathrm{~g} \mathrm{~L}^{-1}$ presented longer rice seedling root lengths than distilled water. No root extract concentrations had significant effects on seed germination, shoot length, and root length.

The allelopathic effect of $S$. zeylanica differed depending on the plant organ. Leaf and stem extracts showed greater allelopathic effect than root extract did. These results were in agreement with what was previously reported in several species, such as Barleria lupulina Lindl., where the aqueous leaf extract showed inhibitory effects on germination, Amaranthus spinosus L., and Echinochloa crus-galli (L.) Beauv. than the stem and root extracts (Poonpaiboonpipat, 2017). Furthermore, the leaf of Peganum harmala L. showed the most inhibitory activity on Avena fatua L. and Convolvulus arvensis L., followed by stem and root parts (Sodaeizadeh et al., 2009). This situation might be because leaves are the main metabolism sites where secondary metabolites are found more often than in other parts of plants (Sisodia et al., 2010; Poonpaiboonpipat, 2017).

Additionally, S. zeylanica leaf extract results at $12.5 \mathrm{~g} \mathrm{~L}^{-1}$ showed higher root length compared to distilled water but demonstrated an inhibitory effect on the root length at 50 and
$100 \mathrm{~g} \mathrm{~L}^{-1}$. This result indicates that the extract performed both stimulatory and inhibitory activities. Allelochemicals can display stimulatory effects at lower concentrations and inhibitory effects at higher concentrations (Regina et al., 2007).

Total phenolic and flavonoid contents in different part extracts of S. zeylanica

The total phenolic and flavonoid contents from aqueous extracts of S. zeylanica leaves, stems, and roots are reported in Table 2. Leaves comprised the highest content of total phenolics (7.36 mg GE g ${ }^{-1} \mathrm{DW}$ ), followed by stems and roots (2.75 and $0.82 \mathrm{mg} \mathrm{GE} \mathrm{g}^{-1} \mathrm{DW}$, respectively). Leaves also contained the highest content of total flavonoids $(254.19 \mu \mathrm{g}$ QE g $\left.{ }^{-1} \mathrm{DW}\right)$, followed by stems and roots (73.13 and $30.40 \mu \mathrm{g}$

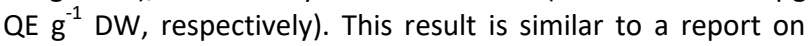
Thymus numidicus Poir., which has more phenols, flavonoids, flavonols, and proanthocyanidins in its leaves than its stems and roots (Ali et al., 2014).

The total number of phenolics and flavonoids were the highest in leaves and the lowest in roots, which might be explained by different processes of biosynthesis and/or degradation, the transport involved in the distribution of these polyphenols at the plant level and phenological organ growth (Fico et al, 2000; Hudaib et al., 2002; Ali et al., 2014). Phenolic and flavonoid compounds in allelopathy and their modes of action appeared in similar actions, such as inhibiting phytopathogens and plant growth, causing non-specific permeability changes on cell membranes, and interacting with several phytohormones and enzymes during the biosynthesis pathway, which resulted in deviations from typical patterns found in the plant (Einhellig, 2004).

\section{Effect of incorporation of S. zeylanica residues in the soil}

Our results show that soil incorporation with non-extracted residue significantly inhibited seed emergence by all rates of incorporation three days after sowing. However, the emergence of $0.5 \%$ soil incorporation was not statistically significant on the fifth and tenth days after sowing. The highest inhibitory effect was detected in $4 \%$ soil incorporation when rice emergence was $21.50 \%, 37.00 \%$, and $57.50 \%$ on the third, fifth, and tenth days after sowing, respectively. The soil incorporation with extracted residue showed no effect on rice emergence (Table 3).

In the case of rice seedling growth, all rates of the soil incorporation with extracted residue reduced the seedling height three weeks after the sowing. However, 28 days after the sowing, the seedling height in the $0.5 \%$ treatment was not statistically significant. Meanwhile, soil incorporation with non-extracted residue caused a decrease in rice shoot biomass (Table 4). The degree of seedling growth inhibition showed an increase in the concentration of non-extracted residue soil incorporation. Although $2 \%$ and $4 \%$ of soil incorporation with non-extracted residue inhibited rice seedling growth, neither of the rates was significant. The soil incorporation with extracted S. zeylanica residue resulted in seedling height and shoot dry weight values similar to the emergence results, where no concentrations affected the seedling growth (Table 4). 
Table 1. Effect of different extracts of S. zeylanica on seed germination and seedling growth of rice variety 'KDML 105'.

\begin{tabular}{|c|c|c|c|c|}
\hline Parts & $\begin{array}{c}\text { Concentrations } \\
\left(\mathrm{g} \mathrm{L}^{-1}\right)\end{array}$ & $\begin{array}{c}\text { Germination } \\
(\%)\end{array}$ & $\begin{array}{l}\text { Shoot length } \\
(\mathrm{cm})\end{array}$ & $\begin{array}{l}\text { Root length } \\
(\mathrm{cm})\end{array}$ \\
\hline \multicolumn{2}{|c|}{ Distilled water (control) } & $100.00 \mathrm{a}$ & $5.63 \mathrm{bc}$ & $5.86 \mathrm{bc}$ \\
\hline \multirow{4}{*}{ Leaves } & 12.50 & $100.00 \mathrm{a}$ & $6.21 \mathrm{ab}$ & $7.64 \mathrm{a}$ \\
\hline & 25.00 & $90.00 \mathrm{a}$ & $5.38 \mathrm{c}$ & $6.77 \mathrm{ab}$ \\
\hline & 50.00 & $35.00 \mathrm{c}$ & $1.68 \mathrm{e}$ & $2.40 \mathrm{~d}$ \\
\hline & 100.00 & $00.00 \mathrm{~d}$ & $0.00 \mathrm{f}$ & $0.00 \mathrm{e}$ \\
\hline \multirow{4}{*}{ Stems } & 12.50 & $100.00 \mathrm{a}$ & $6.41 \mathrm{a}$ & $6.19 \mathrm{bc}$ \\
\hline & 25.00 & $97.50 \mathrm{a}$ & $5.34 \mathrm{c}$ & $5.34 \mathrm{c}$ \\
\hline & 50.00 & $50.00 \mathrm{~b}$ & $2.54 \mathrm{~d}$ & $2.33 \mathrm{~d}$ \\
\hline & 100.00 & $00.00 \mathrm{~d}$ & $0.00 \mathrm{f}$ & $0.00 \mathrm{e}$ \\
\hline \multirow{4}{*}{ Roots } & 12.50 & $100.00 \mathrm{a}$ & $6.43 a$ & $5.77 \mathrm{bc}$ \\
\hline & 25.00 & $100.00 \mathrm{a}$ & $6.44 \mathrm{a}$ & $6.71 \mathrm{abc}$ \\
\hline & 50.00 & $97.50 \mathrm{a}$ & $5.76 \mathrm{abc}$ & $5.76 \mathrm{bc}$ \\
\hline & 100.00 & $97.50 \mathrm{a}$ & $5.02 \mathrm{c}$ & $6.57 \mathrm{abc}$ \\
\hline
\end{tabular}

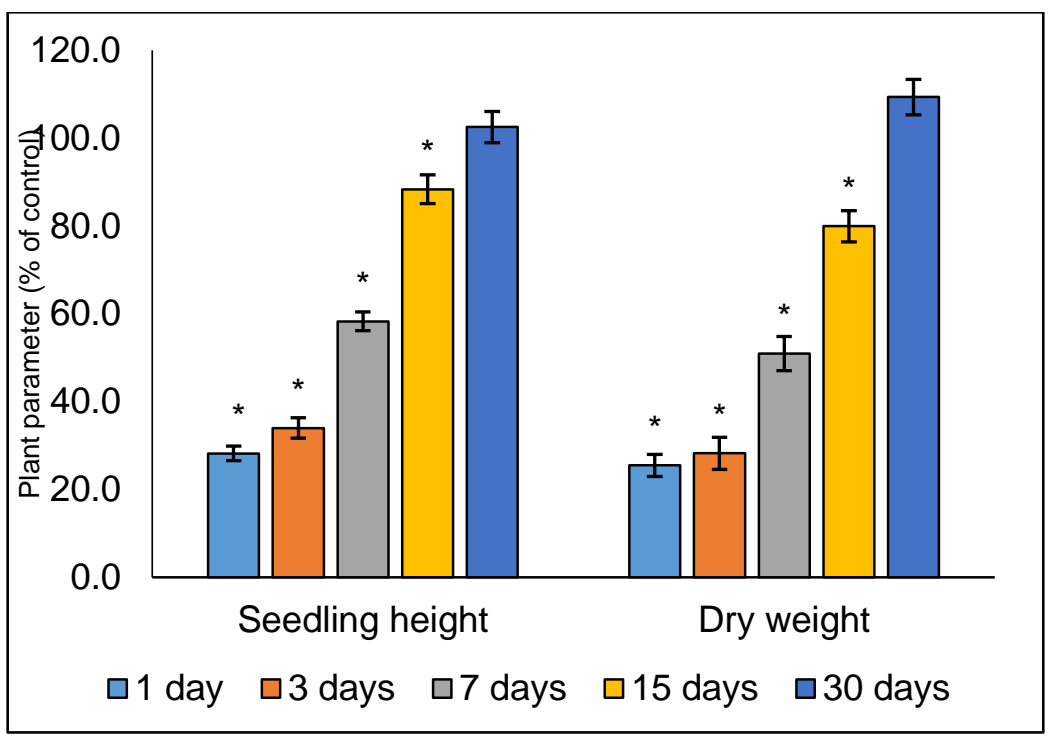

Fig 1. Effect of the soil incorporated with S. zeylanica whole plant residue on the seedling growth of rice when seeds were sown after $1,3,7$, and 15 days after the addition of residues $(2 \% \mathrm{w} / \mathrm{w})$ into the soil. Asterisks $(*)$ indicate significant differences compared to control $(P<0.05)$ after the application of DMRT; bars indicate standard deviation ( \pm SD).

Table 2. Total phenolic content and total flavonoid content of each part extracts of S. zeylanica.

\begin{tabular}{llc}
\hline Parts & $\begin{array}{l}\text { Total phenolic content } \\
\left(\mathrm{mg} \mathrm{GE} \mathrm{g}^{-1} \mathrm{DW}\right)\end{array}$ & $\begin{array}{c}\text { Total flavonoid content } \\
\left(\mu \mathrm{g} \mathrm{QE} \mathrm{g} \mathrm{g}^{-1} \mathrm{DW}\right)\end{array}$ \\
\hline Leaves & $7.36 \pm 0.04 \mathrm{a}$ & $254.19 \pm 2.71 \mathrm{a}$ \\
\hline Stem & $2.75 \pm 0.03 \mathrm{~b}$ & $73.13 \pm 1.45 \mathrm{~b}$ \\
\hline Root & $0.82 \pm 0.01 \mathrm{c}$ & $30.40 \pm 0.80 \mathrm{c}$ \\
\hline
\end{tabular}

Note: Mean values of four replications, with the same letters in each column indicating that the data are not significantly different according to Duncan's multiple range test $(P<0.05)$.

Table 3. Effect of soil incorporation with extracted and non-extracted residues on the emergence of rice seeds.

\begin{tabular}{|c|c|c|c|c|}
\hline \multirow{3}{*}{ Residues } & \multirow{3}{*}{ Rates of soil incorporation (w/w) } & \multicolumn{3}{|c|}{ Emergence (\%) } \\
\hline & & \multicolumn{3}{|c|}{ Days after sowing } \\
\hline & & 3 & 5 & 10 \\
\hline \multicolumn{2}{|c|}{ Control (untreated) } & $100.00 \mathrm{a}$ & $100.00 \mathrm{a}$ & $100.00 \mathrm{a}$ \\
\hline \multirow[t]{4}{*}{ Non-extracted } & $0.5 \%$ & $60.00 \mathrm{~b}$ & 93.75 a & $93.75 \mathrm{a}$ \\
\hline & $1 \%$ & $42.50 \mathrm{c}$ & $61.25 b$ & $72.50 \mathrm{~b}$ \\
\hline & $2 \%$ & $35.00 \mathrm{c}$ & $55.50 \mathrm{~b}$ & $67.50 \mathrm{~b}$ \\
\hline & $4 \%$ & $21.50 \mathrm{~d}$ & $37.00 \mathrm{c}$ & $57.50 \mathrm{c}$ \\
\hline \multirow[t]{4}{*}{ Extracted } & $0.5 \%$ & $100.00 \mathrm{a}$ & $100.00 \mathrm{a}$ & $100.00 \mathrm{a}$ \\
\hline & $1 \%$ & $100.00 \mathrm{a}$ & $100.00 \mathrm{a}$ & $100.00 \mathrm{a}$ \\
\hline & $2 \%$ & $100.00 \mathrm{a}$ & $100.00 \mathrm{a}$ & $100.00 \mathrm{a}$ \\
\hline & $4 \%$ & 95.00 a & $95.00 \mathrm{a}$ & $95.00 \mathrm{a}$ \\
\hline
\end{tabular}


Table 4. Effect of soil incorporation of S. zeylanica residue on the height and dry weight of rice seedlings.

\begin{tabular}{|c|c|c|c|c|c|c|}
\hline \multirow{3}{*}{ Residues } & \multirow{3}{*}{ Rates of soil incorporation $(w / w)$} & \multicolumn{4}{|c|}{ Height $(\mathrm{cm})$} & \multirow{3}{*}{$\begin{array}{l}\text { Dry weight } \\
\text { (g) }\end{array}$} \\
\hline & & \multicolumn{4}{|c|}{ Days after sowing } & \\
\hline & & 7 & 14 & 21 & 28 & \\
\hline \multirow[t]{2}{*}{ Control (untreated) } & & $14.5 \mathrm{a}$ & $29.5 \mathrm{a}$ & $41.0 \mathrm{a}$ & $51.5 \mathrm{a}$ & $50.3 \mathrm{a}$ \\
\hline & $0.5 \%$ & $9.8 \mathrm{~b}$ & $20.4 \mathrm{~b}$ & $31.0 \mathrm{~b}$ & $45.5 \mathrm{a}$ & $45.3 \mathrm{a}$ \\
\hline \multirow{3}{*}{ Non-extracted } & $1 \%$ & $6.4 \mathrm{c}$ & $11.7 \mathrm{c}$ & $20.5 \mathrm{c}$ & $25.5 \mathrm{~b}$ & $28.5 \mathrm{~b}$ \\
\hline & $2 \%$ & $3.4 \mathrm{~d}$ & $7.5 \mathrm{~d}$ & $11.2 \mathrm{~d}$ & $14.5 \mathrm{c}$ & $12.8 \mathrm{c}$ \\
\hline & $4 \%$ & $3.0 \mathrm{~d}$ & $4.9 \mathrm{e}$ & $9.2 \mathrm{~d}$ & $13.5 \mathrm{c}$ & $12.3 \mathrm{c}$ \\
\hline \multirow{4}{*}{ Extracted } & $0.5 \%$ & $13.5 \mathrm{a}$ & $27.5 \mathrm{a}$ & $38.5 \mathrm{a}$ & $50.5 \mathrm{a}$ & $49.5 \mathrm{a}$ \\
\hline & $1 \%$ & $13.4 \mathrm{a}$ & $28.0 \mathrm{a}$ & $39.0 \mathrm{a}$ & $51.3 \mathrm{a}$ & $48.0 \mathrm{a}$ \\
\hline & $2 \%$ & $14.0 \mathrm{a}$ & $28.4 \mathrm{a}$ & $38.5 \mathrm{a}$ & $48.5 \mathrm{a}$ & $48.5 \mathrm{a}$ \\
\hline & $4 \%$ & $13.2 \mathrm{a}$ & $27.0 \mathrm{a}$ & $37.5 a$ & $47.5 \mathrm{a}$ & $47.8 a$ \\
\hline
\end{tabular}

Note: Mean values of four replications, with the same letters in each column indicating that the data are not significantly different according to Duncan's multiple range test $(P<0.05)$.

Soil incorporation with allelopathic residue is one of the allelochemicals released through the environment in natural and agricultural ecosystems. The present study's results for $S$. zeylanica soil incorporation with non-extracted residue exhibited an inhibitory effect on rice seedling growth; however, the incorporation with extracted residue did not inhibit rice growth. This is evidence of allelopathy caused by the compound in S. zeylanica that Laosinwattana et al. (2007) supported, where soil incorporation and soil mulching with Vetiveria spp. leaf residues inhibited Raphanus sativus L. seedling growth more than residues extracted by methanol at equal concentrations. This result showed that the soil incorporation of extracted residue did not affect rice seedling growth when compared with the control. Soil incorporation with non-extracted residue showed an inhibitory effect on rice at equal rates, which indicates that the metabolites removed from the residue by methanol were the key reason for the inhibitory activity of soil incorporation, and thus, emphasizes the allelopathic effect of $S$. zeylanica residue.

\section{Effect of decomposition of S. zeylanica residues in the soil incorporation}

The inhibitory effect of soil incorporation with non-extracted $S$. zeylanica residue on rice seedling growth significantly persisted when rice seeds were sown for $1,3,7$, and 15 days after the soil amendment. The inhibition degrees of seedling height were $71.8 \%, 66.0 \%, 41.7 \%$, and $11.7 \%$, respectively, while the inhibition degrees of dry weight were $74.6 \%, 71.8 \%$, $49.1 \%$, and $20.1 \%$, respectively. Inhibition effects disappeared when rice seeds were sown in the soil 30 days after the residue incorporation (Fig 1).

The time after soil incorporation is the main season for allelopathic action (Sodaeizadeh et al., 2010). Phytotoxic activity generally occurs in the early decomposition stages (Kobayashi, 2004). The results of the present study indicated that S. zeylanica residues' high inhibition effect on rice growth was obtained on the first or third day after the decay started, while the inhibitory effect disappeared on the $13^{\text {th }}$ day. This result was in agreement with Sodaeizadeh et al. (2010), who reported that the maximum phytotoxic effect of Peganum harmala L. soil incorporation was executed one to three days after the decay started and that phytotoxicity was initially reduced on the seventh day before disappearing on the $15^{\text {th }}$ days. Sampietro et al. (2007) reported similar findings, which denoted that the maximum phytotoxicity of sugarcane (Saccharum officinarum L.) straw leachate was obtained when arrowleaf sida (Sida rhombifolia L.) seeds were sown zero, one, or two days after Saccharum officinarum L. was incorporated into the soil. After 10 days, the inhibition effect disappeared. The residue decomposition in soil may be caused by chemical decomposition, microbial degradation, leaching, and the adsorption of phytotoxins (Ismail and Chong, 2002; Kobayashi, 2004; Sampietro et al, 2007).

\section{Materials and Methods}

\section{S. zeylanica samples}

S. zeylanica individuals were harvested as a whole plant at the maturing stage (45 days after seedling) in August 2018 from a paddy field in the Phitsanulok province, Thailand. The samples were cleaned; separated into leaves, stems, and roots; and then dried in a drying oven at $40^{\circ} \mathrm{C}$. The dried materials were ground into powder using an electric grinder, and then the powder was kept in dark and cool conditions for further use.

\section{Bioassay seeds}

Rice seeds variety 'KDML 105 ' was used as a test plant species for the determined inhibitory effect of $S$. zeylanica extracts. The seeds were soaked in distilled water for $24 \mathrm{~h}$ and then incubated in a plastic box lined with a clean moisture textile for another $24 \mathrm{~h}$. The germinating rice seeds were dipped in $1 \%$ sodium hypochlorite for $1 \mathrm{~min}$ and then rinsed with distilled water several times before use.

\section{Bioassay with different part extracts of S. zeylanica}

The leaf, stem, and root powders were prepared for extraction. One hundred grams of each material were extracted with distilled water by $1 \mathrm{~L}$ and kept at $14^{\circ} \mathrm{C}$ for $72 \mathrm{~h}$. The extract was filtered through No. 1 filter paper, receiving a stock of $100 \mathrm{~g} \mathrm{~L}^{-1}$. The stock of leaf, stem, and root was diluted to provide concentrations of $12.5,25,50$, and $100 \mathrm{~g} \mathrm{~L}^{-1}$. Each extract was tested on their allelopathic effect on rice using the Petri test bioassay method: $5 \mathrm{~mL}$ of aliquot extract and concentration were added to the $9 \mathrm{~cm}$ petri dish lined with germination paper. The 10 germinating rice seeds were placed into the Petri dish, which was sealed with Parafilm. Petri dishes were placed in a laboratory at $25-32^{\circ} \mathrm{C}$. A completely randomized design was used. Each treatment was replicated four times. Distilled water was used as the control. 


\section{Analysis of total phenolic and flavonoid contents in different part extracts of $S$. zeylanica}

S. zeylanica leaf, stem, and root extracts were prepared in the same way as the experiment above and they were used at concentrations of $12.5-100 \mathrm{~g} \mathrm{~L}^{-1}$ to analyze total phenolic and flavonoid content. A modified version of Poonpaiboonpipat and Poolkum (2019) Folin-Ciocalteu method was used to determine the total phenolic content: $2 \mathrm{~mL}$ of the sample was transferred to a test tube before $10 \mathrm{~mL}$ of Folin-Ciocalteu reagent and $8 \mathrm{~mL}$ of $7.5 \%$ sodium carbonate were mixed. The mixture was incubated at room temperature for $2 \mathrm{~h}$, and the reaction solution was measured by absorbance at $765 \mathrm{~nm}$ using an ultraviolet (UV) spectrophotometer. Each part's total phenolic content was expressed as milligram gallic acid equivalent per gram of plant dry weight ( $\mathrm{mg} \mathrm{GE} \mathrm{g}^{-1} \mathrm{DW}$ ).

Total flavonoid content was measured using the aluminum chloride colorimetric assay (Prommuak et al., 2008); $0.5 \mathrm{~mL}$ of each aqueous extract was mixed with $10 \%$ of aluminum chloride by $0.1 \mathrm{~mL}$ and $1 \mathrm{M}$ of potassium acetate by $0.1 \mathrm{~mL}$. The mixer adjusted the volume to $10 \mathrm{~m}$ and then was incubated at $25^{\circ} \mathrm{C}$ for $30 \mathrm{~min}$. Absorbance of each solution was measured by a UV spectrophotometer at $415 \mathrm{~nm}$. The total flavonoid contents of each part were expressed as microgram quercetin equivalent per gram of plant dry weight ( $\mu \mathrm{g} Q \mathrm{Q} \mathrm{g}^{-1}$ DW).

\section{Incorporation of S. zeylanica residues in the soil}

This experiment aimed to detect the allelopathic effect of incorporation of S. zeylanica residues in the soil on rice seedling growth. The method was adapted from Laosinwattana et al. (2007). S. zeylanica powder was separated into two parts: the first (non-extracted residue) was kept in dark and cool conditions, while the second (extracted residue) was extracted three times using $95 \%$ of the methanol to remove metabolites in the plant cell and then dried in a hot air oven at $60^{\circ} \mathrm{C}$.

A glasshouse condition was used in this experiment. Natural paddy soil that had been herbicide-free for two years was collected at $30-\mathrm{cm}$ depth. The soil was dried under sunlight and pounded into small pieces (less than $1 \mathrm{~cm}$ ). The treatments included two factors: non-extracted powder and extracted powder, each of which included $0.5 \%, 1 \%, 2 \%$, and $4 \% \mathrm{w} / \mathrm{w}$. The non-incorporation pot was used as a control.

Seven kilograms of dry soil was placed into a $30 \mathrm{~cm} \times 40 \mathrm{~cm}$ plastic pot. S. zeylanica powder, depending on treatments, was added to the pot and then incorporated by hand. Tap water was added to the pot until the soil was saturated. Similar to the previous experiment, 10 germinating rice seeds were sown in the pot. Each treatment was replicated four times. Rice emergence and seedling height were measured 3, 7, 15, and 30 days after sowing. Ten days after sowing, the seedlings were thinned to five plants per pot. Shoots were harvested and dried at 35 days after sowing.

\section{Decomposition of $S$. zeylanica residues in the soil incorporation}

An additional experiment was conducted to investigate the effect of S. zeylanica residues' decomposition period on rice growth in terms of seedling growth. This study used $2 \% \mathrm{w} / \mathrm{w}$ of S. zeylanica residues in the soil incorporation, similar to the previous experiment. The soil mixture was placed in a glasshouse for $1,3,7,15$, and 30 days before bioassay. Every day, $500 \mathrm{~mL}$ of tap water was added to pots. Ten rice seeds were sown into each pot in various amendment soils. The control treatment received only tap water. Ten days after sowing, plants were thinned to five seedlings per pot. Each treatment was replicated four times. Data on seedling height and shoot dry weight were recorded 30 days after sowing.

\section{Statistical analyses}

A completely randomized design was used for the experiments in a laboratory. A pot experiment with a randomized block design was conducted in a glasshouse. Each treatment was replicated four times and the mean value per replication was used for statistical analyses. All data were analyzed using analysis of variance (ANOVA). Wherever ANOVA indicated significant effects $(P<0.05)$, a pairwise comparison of means was made using Duncan's new multiple range test (DMRT).

\section{Conclusions}

The present study indicated that $S$. zeylanica residues has potent allelopathic activity on rice seedling growth. Leaf and stem extracts demonstrated higher inhibitory effects on rice than root extracts because they contained greater amounts of phenolic compounds. Whole residue incorporation in soil inhibited seed emergence and seedling growth under increasing concentrations. Finally, the suppression of both weed species by $S$. zeylanica residues was inversely proportional to the time after the application of plant materials and S. zeylanica performed its allelopathic effect on rice in paddy in the field.

\section{Acknowledgments}

This work was supported by Naresuan University Government budget grant number R2561B047.

\section{References}

Ali BEH, Bahri R, Chaouachi M, Boussaïd M, Harzallah-Skhiri F (2014) Phenolic content, antioxidant and allelopathic activities of various extracts of Thymus numidicus Poir. organs. Ind Crops Prod. 62:188-195.

Babu GP, Vinita H, Audiseshamma K, Paramageetham C (2014) Allelopathic effects of some weeds on germination and growth of Vigna mungo (L). Hepper. Int J Curr Microbiol App Sci. 3(5):122-128.

Bashir T, Anum W, Ali I, Ghaffar A, Ali L, Raza MU, Javed Z, Zafar A, Mahmood N, Shabir A (2018) Allelopathic effects of perennial sow thistle (Sonchus arvensis L.) on germination and seedling growth of maize (Zea mays L.). Allelopathy J. 43(1):105-116.

Chootummatat S, Hongtrakul V, Thongdeethae S, Pongprasert S, Panpeng V, Intalaeng V (1994) Survey on weeds in farmers' fields in the Central Plain of Thailand. Annual report, Pathum Thani Rice Research Center, Rice Research Institute, Department of Agriculture, Bangkok, Thailand. 
Einhellig FA (2004) Mode of allelochemical action of phenolic compounds. In: Macías FA, Galindo JCG, Molinillo JMG, Cutler HG (ed) Allelopathy: chemistry and mode of action on allelochemicals, CRC Press, London, UK. 217-238.

Fico G, Bilia AR, Morelli I, Tomè F (2000) Flavonoid distribution in Pyracantha coccinea plants at different growth phases. Biochem Syst Ecol. 28(7):673-678.

Fu YH, Quan WX, Li CC, Qian, CY, Tang FH, Chen XJ (2019) Allelopathic effects of phenolic acids on seedling growth and photosynthesis in Rhododendron delavayi Franch. Photosynthetica. 57(2):377-387.

Holm LG, Plucknett DL, Pancho JV, Herberger JP (1977) The world's worst weeds. Honolulu (Haw., USA): East-West Center. University Press of Hawaii. 446-449.

Hudaib M, Speroni E, Di Pietra AM, Cavrini V (2002) GC/MS evaluation of thyme (Thymus vulgaris L.) oil composition and variations during the vegetative cycle. J pharm Biomed Anal. 29(4):691-700.

Inderjit (1996) Plant phenolics in allelopathy. Bot Rev. 62:186202

Ismail BS, Chong TV (2002) Effects of aqueous extracts and decomposition of Mikania micrantha H.B.K debris on selected agronomic crops. Weed Biol. Manag. 2(1):31-38.

Kobayashi K (2004) Factors affecting phytotoxic activity of allelochemicals in soil. Weed Biol Manag. 4(1):1-7.

Laosinwattana C, Phuwiwat W, Charoenying P (2007) Assessment of allelopathic potential of Vetivergrass (Vetiveria spp.) ecotypes. Allelopathy J. 19(2):469-478.

Majeed MA, Tanveer A, Tahir M, Ahmad R (2018) Soil Mediated Allelopathic Effect of Echinochloa colona on Germination and Seedling Growth of Zea mays. Planta Daninha. 36:1-12.

Poonpaiboonpipat T (2017) Allelopathic Effect of Barleria lupulina Lindl. on Germination and Seedling Growth of Pigweed and Barnyardgrass. Naresuan University J: Sci Technol. 25(4):44-50.

Poonpaiboonpipat T, Poolkum S (2019) Utilization of Bidens pilosa var. radiata (Sch. Bip.) Sherff integrated with water irrigation for paddy weed control and rice yield production. Weed Biol Manag. 19(2):31-38.
Premasthira C, Zungsontiporn S (1998) Allelopathic effects of gooseweed extracts on growth of weed seedlings. In Odofsdotter M, Allelopathy in Rice: Int Rice Res Inst, Philippines.

Prommuak C, De-Eknamkul W, Shotipruk A (2008) Extraction of flavonoids and carotenoids from Thai silk waste and antioxidant activity of extracts. Sep Puri Technol. 62(2):444448.

Regina GB, Edivaldo DV, Duke SO (2007) Dose/response relationships in allelopathy research. In: Fujii Y, Hiradate $S$ (ed) Allelopathy: New concepts and Methodology: Science Publishers, Inc. Endfield, NH, USA. 3-30.

Rice EL (1984) Allelopathy, 2nd ed. Olendo: Acacemic Press, Inc.

Sampietro DA, Sgariglia MA, Soberón JR, Quiroga EN, Vattuone MA (2007) Role of sugarcane straw allelochemicals in the growth suppression of arrowleaf sida. Environ Exper Botany 60(3):495-503.

Sisodia S, Siddiqui MB (2010) Allelopathic effect by aqueous extracts of different parts of Croton bonplandianum Baill. on some crop and weed plants. J Agric Ext Rural Dev. 2(1):22-28.

Sodaeizadeh H, Rafieiolhossaini M, Havlík J, Van Damme P (2009) Allelopathic activity of different plant parts of Peganum harmala L. and identification of their growth inhibitors substances. Plant Growth Regul. 59(3):227-236.

Sodaeizadeh H, Rafieiolhossaini M, Van Damme P (2010) Herbicidal activity of a medicinal plant, Peganum harmala $\mathrm{L}$., and decomposition dynamics of its phytotoxins in the soil. Ind Crops Prod. 31(2):385-394.

Torres A, Olivia RM, Castellano D, Cross P (1996) A science of the future. In: Proceedings of the 1st World Congress on Allelopathy. Cadiz, Spain: University of Cadiz: 278.

Xuan TD, Tawata S, Khanh TD, Chung IM (2005) Decomposition of allelopathic plants in soil. J Agron Crop Sci. 191(3):162171.

Zeng RS, Mallik AU, Luo SM (2008) Allelopathy in Sustainable Agriculture and Forestry (Eds.). New York: Springer. 189-282. 